\title{
HUBUNGAN ANTARA PENGETAHUAN MIKROBIOLOGI DENGAN SIKAP HYGIENE MAHASISWA AKPER KESDAM I/BB PADANG
}

\author{
Vevi Kurniawati \\ Akademi Keperawatan Kesdam I/BB Padang \\ Email : vevikurniawati444@gmail.com
}

\begin{abstract}
ABSTRAK
Penyakit yang terjadi pada manusia salah satunya dapat disebabkan oleh mikroorganisme patogen yang muncul akibat sikap yang tidak hygiene dalam kehidupan sehari hari. Sikap hygiene merupakan sikap yang menjadi bagian tak dapat terpisahkan dari kehidupan manusia. Sikap hygiene bisa dicapai dengan adanya pengetahuan mikrobiologi yang benar yang dapat meningkatkan tingkat kebersihan. Tujuan penelitian ini untuk mengetahui hubungan antara pengetahuan mikrobiologi dengan sikap hygiene mahasiswa Akper Kesdam I/BB Padang. Metode penelitian yang digunakan adalah metode survei dengan studi korelasional. Populasi dalam penelitian ini yaitu mahasiswa semester 3 dan 6 yang telah mengambil mata kuliah mikrobiologi sebanyak 82 orang. Pengambilan sampel dengan menggunakan teknik random sampling sebanyak 40 orang. penelitian dilakukan pada bulan Desember 2020. Hasil penelitian ini didapatkan kedua variabel memiliki hubungan dengan kontribusi $11,4 \%$ terhadap taraf signifikan $\mathrm{a}=0,05(5 \%)$ dimana $r$ hitung $(0,338)>r$ tabel $(0,312)$.
\end{abstract}

Kata Kunci : Pengetahuan, mikrobiologi, sikap hygiene.

\section{ABSTRACT}

One of the diseases that occurs in humans can be caused by pathogenic microorganisms that arise due to unsanitary attitudes in everyday life. An attitude of cleanliness, an attitude that is an inseparable part of human life. Hygiene attitudes can be achieved with knowledge of microbiology which can actually improve hygiene levels. The purpose of this study was to see the relationship between microbiological knowledge and the hygiene attitude of the students of Akper Kesdam I/BB Padang. The research method used is a survey method with a correlational study. The population in this study were 82 students in semester 3 and 6 who had taken microbiology courses. Sampling using random sampling technique as many as 40 people. The study was conducted in December 2020. The results showed that the second variable had a relationship with a contribution of $11.4 \%$ to the significant level $a=0.05(5 \%)$ where $r$ count $(0.338)>r$ table (0.312).

Keywords: Knowledge, microbiology, hygiene attitude. 
Vol.2.No 2 (2020)

p-ISSN :2657-2435

e-ISSSN:2721-3145

\section{PENDAHULUAN}

Mikrobiologi merupakan sebuah cabang ilmu biologi yang mempelajari tentang organisme yang bersifat mikroskopis, mikrobiologi ini erat kaitannya dalam kehidupan sehari-hari. terdapat lima kelompok mikroorganisme, yaitu bakteri, protozoa, virus, algae serta cendawan (jamur) mikroskopik (Hiaranya dkk, 2017). Beberapa di antaranya bermanfaat dan yang lainnya merugikan. Mikroorganisme banyak terdapat di alam dan memiliki peranan yang besar, termasuk dalam bidang kesehatan, maka sudah selayaknya setiap mahasiswa yang belajar mikrobiologi mengetahui hal-hal yang terkait dengan mikrobiologi (Yodong dkk., 2019).

Mikroorganisme yang merugikan bagi manusia atau mikroorganisme patogen dapat menimbulkan penyakit. hal ini dapat disebabkan oleh pola hidup tidak bersih, seperti kebersihan diri dan lingkungan. Hal seperti ini dapat dicegah melalui upaya penyehatan lingkungan dan peningkatan sikap hygiene dari masingmasing individu dalam meminimalisir penyebaran dari penyakit menular tersebut salah satunya adalah dengan menanamkan pengetahuan mengenai agen penyebab penyakit, sehingga dapat mewujudkan sikap peduli terhadap kesehatan pada diri masing-masing. Pengetahuan mengenai sifat-sifat agen penyebab penyakit sangat penting dalam pencegahan dan penanggulangan penyakit (Devkota, H. R., et. al, 2017). Pengetahuan tentang sifat-sifat agen tersebut dapat diperoleh dengan mempelajari mikrobiologi.
Pengetahuan tentang kesehatan bagi mahasiswa khususnya keperawatan harus menjadi prioritas utama dalam kehidupan manusia. Sehingga mahasiswa calon perawat ini diharapkan mampu mengaplikasikan pengetahuan mikrobiologinya berupa menjaga sikap hygiene agar dapat meningkatkan kebersihan diri dan lingkungan agar terciptanya hidup yang sehat, baik untuk dirinya pribadi maupun orang-orang disekitarnya. untuk itu, diharapkan dengan tingkat kognitif yang dimiliki mahasiswa harus mampu mempunyai sikap positif terhadap pengetahuan yang dimilikinya sehingga mereka mampu mengembangkan dan membina sikap positif terhadap kesehatan.

Berdasarkan uraian diatas, maka perlu dilakukan penelitian tentang hubungan pengetahuan mikrobiologi dengan sikap hygiene mahasiswa Akper Kesdam I/BB padang. Penelitian ini bertujuan untuk mengetahui hubungan pengetahuan mikrobiologi dengan sikap hygiene mahasiswa Akper Kesdam I/BB padang.

\section{METODE PENELITIAN}

Metode penelitian yang digunakan dalam penelitian ini adalah metode survey dengan studi korelasional. Pengambilan sampel dalam penelitian ini menggunakan teknik simple random sampling. Populasi penelitian ini adalah mahasiswa semester 3 dan 6 yang telah mengambil mata kuliah mikrobiologi sebanyak 82 orang dengan sampel sebanyak 40 orang.

Instrumen penelitian menggunakan kuisioner sebagai alat pengukur pengetahuan mikrobiologi 
dan sikap hygiene mahasiswa. Analisis data yang digunakan untuk mengukur hubungan antara pengetahuan mikrobiologi dengan sikap hygiene adalah menggunakan analisis uji chisquare dengan taraf signifikansi $\alpha=0,05$ (5\%).

\section{HASIL}

\section{Pengetahuan Mikrobiologi}

Berdasarkan hasil tes pengetahuan mikrobiologi yang telah dilakukan terhadap 40 responden, didapatkan hasil sebagai berikut:

Tabel 1. Hasil Tes Pengetahuan Mikrobiologi

\begin{tabular}{ccccc}
\hline \multicolumn{3}{c}{$\begin{array}{c}\text { No. } \\
\text { Skerval Kategori Frekuensi } \\
\text { Skor }\end{array}$} & $\begin{array}{c}\text { Persentase } \\
(\%)\end{array}$ \\
\hline 1. & $0-34$ & $\begin{array}{l}\text { Sangat } \\
\text { rendah }\end{array}$ & 0 & 0 \\
2. & $35-54$ & Rendah & 0 & 0 \\
3. & $55-64$ & Sedang & 9 & 22,5 \\
4. & $65-84$ & Tinggi & 17 & 42,5 \\
5. & $85-100$ & Sangat & 14 & 35 \\
& & Tinggi & & \\
\hline & Jumlah & 40 & 100
\end{tabular}

Berdasarkan tabel di atas, diperoleh hasil dari tes pengetahuan mikrobiologi persentase skor yang paling banyak adalah pada kategori Tinggi, yaitu 42,5\% (17 responden) diikuti kategori Sangat Tinggi, yaitu $35 \%$ (14 responden). Sedangkan persentase skor yang paling sedikit adalah pada kategori Sangat Rendah dan Rendah, yaitu 0\%.

\section{Sikap Hygiene Mahasiswa}

Berdasarkan hasil analisis deskriptif yang telah dilakukan terhadap 40 responden pada angket sikap hygiene mahasiswa maka didapatkan hasil sebagai berikut :
Tabel 2. hasil analisis statistik deskriptif pada angket sikap hygiene.

\begin{tabular}{ccccc}
\hline No. & $\begin{array}{c}\text { Interval Kategori Frekuensi } \\
\text { Skor }\end{array}$ & $\begin{array}{c}\text { Persentase } \\
(\%)\end{array}$ \\
\hline 1. & $1-24$ & Tidak & 0 & 0 \\
2. & $25-48$ & $\begin{array}{c}\text { Baik } \\
\text { Kurang } \\
\text { Baik }\end{array}$ & 0 & 0 \\
3. & $49-72$ & $\begin{array}{c}\text { Cukup } \\
\text { Baik }\end{array}$ & 0 & 0 \\
4. & $73-96$ & $\begin{array}{c}\text { Baik } \\
\text { 5. }\end{array}$ & 21 & 52,5 \\
& $97-120$ & $\begin{array}{c}\text { Sangat } \\
\text { Baik }\end{array}$ & 19 & 47,5 \\
\hline & Jumlah & 40 & 100 \\
\hline
\end{tabular}

Berdasarkan tabel di atas, diperoleh hasil angket sikap hygiene mahasiswa dengan persentase skor yang paling banyak adalah pada kategori Baik, yaitu 52,5 \% (21 responden), diikuti kategori Sangat Baik yaitu 47,5 \% $\quad$ (19 responden). Sedangkan persentase skor yang sedikit adalah pada kategori Tidak Baik, Kurang Baik dan Cukup Baik, yaitu 0\%.

\section{PEMBAHASAN}

\section{Pengetahuan Mikrobiologi}

Berdasarkan hasil tes pengetahuan mikrobiologi didapatkan persentase skor yang paling banyak adalah pada kategori Tinggi, yaitu 42,5 \% (17 responden) kemudian kategori Sangat Tinggi, yaitu $35 \%$ (14 responden). Sementara nilai ratarata yang diperoleh dari tes pengetahuan mikrobiologi adalah sebesar 75,4 dengan kategori Tinggi yaitu pada interval 65-84, jadi dapat disimpulkan bahwa mahasiswa Akper Kesdam I/BB Padang memiliki pengetahuan mikrobiologi yang Tinggi.

Pengetahuan mikrobiologi yang diukur pada mahasiswa yang menjadi responden meliputi 
Vol.2.No 2 (2020)

p-ISSN :2657-2435

e-ISSSN:2721-3145

beberapa indikator, yaitu tinjauan umum mikrobiologi, klasifikasi mikroorganisme, daur hidup mikroorganisme, peranan mikroorganisme, efek terjadinya infeksi yang disebabkan mikroorganisme, dan penyakit yang ditimbulkan oleh mikroorganisme. Pengetahuan tentang mikrobiologi ini memiliki hubungan yang sangat erat dengan kondisi kesehatan, dimana mikroorganisme dapat menjadi penyebab timbulnya penyakit. Oleh karena itu, dalam kehidupan sehari-hari perlunya memiliki pengetahuan tentang mikrobiologi sehingga dapat meningkatkan sikap hygiene seseorang agar terhindar dari penyakit yang disebabkan oleh mikroorganisme, seperti virus, bakteri, jamur, protozoa maupun alga. Infeksi dari mikroorganisme tersebut merupakan agen penyebab timbulnya penyakit (Kusuma, 2011).

Pengetahuan tentang mikroorganisme tidak hanya sebagai informasi, diharapkan dengan tingkat kognitif yang dimiliki mahasiswa harus mampu mempunyai sikap positif terhadap materi mikroorganisme yang mereka pelajari sehingga mereka mampu mengembangkan dan membina sikap positif terhadap kesehatan. Tingkat kognitif yang telah dimiliki mahasiswa pada mikrobiologi yang baik dapat dihubungkan dengan fakta-fakta atau fenomena yang ada pada kehidupan sekitarnya, seperti adanya permasalahan tentang penyakit menular.

\section{Sikap Hygiene}

Berdasarkan hasil analisis nilai sikap hygiene mahasiswa didapatkan persentase skor yang paling banyak adalah pada kategori baik, yaitu $52,5 \%$ (21 responden). Jika dilihat dari nilia rata-rata hasil analisis angket yang didapatkan yaitu sebesar 92, berada pada interval 73-96 dengan kategori baik. Sehingga dapat disimpulkan bahwa mahasiswa Akper Kesdam I/BB Padang memiliki sikap higyene yang Baik.

Hal ini kemungkinan bahwa sikap hygiene mahasiswa terhadap kesehatan merupakan kecenderungan mahasiswa untuk bertindak yang mengindahkan dan memperhatikan segala halhal yang berkaitan dengan kesehatan.

Sikap merupakan suatu respon atas segala sesuatu, yang biasanya berupa penerimaan atau penolakan. Sikap akan menghasilkan suatu tindakan (Wijaya, 2019). Kesadaran mahasiswa Akper Kesdam I/BB Padang dalam menjaga hygiene dapat dilihat dari sikap yang akan menghasilkan tindakan sebagai kesadaran terhadap hygiene agar terhindar dari berbagai penyakit khususnya yang disebabkan oleh mikroorganisme patogen.

Menurut Mustikawati (2013), pengetahuan tentang pentingnya sikap hygiene dan implikasinya terhadap kesehatan merupakan salah satu faktor yang dapat mempengaruhi sikap hygiene, terdapat beberapa faktor lain yg juga dapat mempengaruhi sikap hygiene yaitu citra tubuh, praktik sosial (kelompok-kelompok sosial), status sosio ekonomi, kebudayaan, 
Vol.2.No 2 (2020)

p-ISSN :2657-2435

e-ISSSN:2721-3145

pilihan pribadi dalam menggunakan produk untuk perawatan diri, serta kondisi fisik.

Beberapa kategori kebersihan yang perlu diperhatikan seperti menjaga kebersihan kulit dengan melakukan mandi minimal 2 kali sehari. Mandi merupakan salah satu cara membersihkan kulit. Mandi berguna untuk menghilangkan kotoran yang melekat pada kulit, menghilangkan bau keringat, merangsang peredaran darah dan syaraf, melemaskan otototot, dan memberi kesegaran kepada tubuh (Maryunani, 2013). tidak menjaga kebersihan kulit akan dapat menimbulkan penyakit infeksi. Penyakit infeksi pada kulit menurut Harahap (2000) diambil dari Sajida dkk (2013) infeksi kulit yang dapat terjadi adalah eksim atau dermatitis, psioriasis, jerawat, cacar air, campak, herpes zoster, kanker kulit, impetigo, bisul, kusta, panu, kudis serta timbulnya ketombe.

Selanjutnya dengan menjaga kebersihan tangan dan kuku. membersihkan tangan menggunakan sabun dan air mengalir dapat membunuh bakteri yang ada di tangan. sedangkan untuk kebersihan kuku Menurut Stevens (2000), dapat mengembalikan batas-batas kulit ditepi kuku ke keadaan normal serta dapat mencegah terjadinya perkembangan kuman penyakit, oleh karena itu perlu perawatan kuku dengan cara menggunting kuku sekali seminggu dan menyikat kuku menggunakan sabun. kemudian menjaga kebersihan pakaian, Menurut Irianto (2007) diambil dari Sajida dkk (2013), pakaian banyak menyerap keringat dan kotoran yang dikeluarkan oleh kulit. Pakaian bersentuhan langsung dengan kulit sehingga apabila pakaian yang basah karena keringat dan kotor akan menjadi tempat berkembangnya bakteri di kulit. Pakaian yang basah oleh keringat akan menimbulkan bau.

Faktor lain yang berpengaruh pada status kesehatan seperti sanitasi lingkungan mencakup perumahan, pembuangan kotoran, penyediaan air bersih, dan sebagainya. Kesehatan lingkungan bisa berakibat positif terhadap kondisi elemen-elemen hayati dan non hayati dalam ekosistem. Bila lingkungan tidak sehat maka sakitlah elemennya, tapi sebaliknya jika lingkungan sehat maka sehat pulalah ekosistem tersebut. Perilaku yang kurang baik dari manusia telah mengakibatkan perubahan ekosistem dan timbulnya sejumlah masalah sanitasi yang berdampak kepada status kesehatan (Sajida dkk. 2013)

Menurut pernyataan saryono \& Widianti (2011) mengenai kebersihan perorangan, menyatakan bahwa untuk dapat meminimalkan mikroorganisme yang menjadi penyebab penyakit, maka hal yang paling diperlukan adalah menjaga kebersihan diri atau personal hygiene. Hal ini dipertegas oleh Notoatmodjo (2010) mengenai kebersihan diri yang mengemukakan bahwa dalam meningkatkan derajat kesehatan seseorang dapat dilakukan dengan meningkatkan pemeliharaan personal hygiene yang dilakukan oleh individu sebagai upaya pencegahan penyakit. 
Vol.2.No 2 (2020)

p-ISSN :2657-2435

e-ISSSN:2721-3145

Dalam upaya pencegahan terhadap penyakit khususnya penyakit yang disebabkan oleh mikroorganisme juga diperlukan adanya sikap peduli terhadap kebersihan lingkungan. Menurut Jamanti (2014) kesadaran lingkungan hidup dapat diukur dengan empat indikator, yang satu sama lain berkaitan sebagai sebuah tahapan, yakni pengetahuan, sikap, serta pola perilaku (tindakan).

\section{Hubungan antara Pengetahuan Mikrobiologi dengan Sikap Hygiene} Mahasiswa Akper Kesdam I/BB Padang.

Nilai rata-rata yang diperoleh dari hasil tes pengetahuan mikrobiologi yaitu sebesar 75,4 dengan kategori tinggi karena berada pada interval 65-84, sedangkan nilai rata-rata yang diperoleh dari hasil analisis angket sikap higyene yaitu sebesar 92 dan termasuk kategori baik karena berada pada interval 73-96.

Setelah dilakukan analisis statistik didapatkan hasil $r$ hitung diketahui sebesar $=0,338$, dan $r$ tabel sebesar $=0,312$, Jika $r$ hitung lebih besar dari $r$ tabel maka Ha diterima dan Ho ditolak. Dari hasil perhitungan $r$ hitung sebesar 0,338 dibandingkan dengan $\mathrm{r}$ tabel $(\mathrm{df}=38)$ yaitu 0,312 dengan taraf signifikan 5\%, jadi r hitung $>\mathrm{r}$ tabel maka Ha diterima dan Ho di tolak. Dengan kata lain menolak hipotesis nol (Ho) dan menerima hipotesis alternatif $(\mathrm{Ha})$ untuk pengujian kedua variabel, sehingga dapat disimpulkan bahwa variabel $\mathrm{X}$ terdapat hubungan yang signifikan terhadap variabel $Y$. Dari hasil pengujian hipotesis tersebut terbukti bahwa "terdapat hubungan antara pengetahuan mikrobiologi dengan sikap hygiene mahasiswa Akper Kesdam I/BB Padang. maka selanjutnya untuk mengetahui seberapa besar pengaruh variabel $\mathrm{X}$ (pengetahuan mikrobiologi) terhadap variabel Y (sikap hygiene) dengan menggunakan koefisien determinan $\mathrm{r} 2$ yang dinyatakan dalam persentase. Hasilnya yaitu 11,4\%, Dari hasil perhitungan di atas maka dapat disimpulkan bahwa terdapat pengaruh variabel $\mathrm{X}$ terhadap $\mathrm{Y}$ sebesar $11,4 \%$ dan selebihnya yang $88,6 \%$ dipengaruhi oleh faktor lain.

Penelitian ini sesuai dengan penelitian Hasmiati (2016) yang menyimpulkan bahwa adanya hubungan antara pengetahuan mikrobiologi dengan sikap higienis mahasiswa dengan kontribusi sebesar $24,1 \%$ dan diperkuat oleh Rizqah dkk (2019) yang menyimpulkan bahwa pengetahuan dalam mikrobiologi yang dimiliki mahasiswa berkontribusi sebesar 92,16\% terhadap kepedulian pada kesehatan.

Jadi, dari penelitian ini dapat dikatakan bahwa tingginya pengetahuan mikrobiologi dari mahasiswa yang meliputi materi virus, bakteri, jamur, protista dan alga yang bersifat patogen, serta faktor-faktor yang berkaitan dengan pertumbuhan mikroba, dapat mempengaruhi sikap hygiene mahasiswa untuk memelihara kebersihan agar dapat mencegah bahaya penyakit dari mikroorganisme yang bersifat patogen. Hal tersebut dapat dilihat dari hasil analisis data penelitian yang menunjukkan bahwa mahasiswa mampu menjaga kebersihan kulit, kebersihan tangan dan kuku, mulut dan 
Vol.2.No 2 (2020)

p-ISSN :2657-2435

e-ISSSN:2721-3145

gigi, kebersihan makanan dan minuman, penggunaan air bersih kebersihan pakaian serta kebersihan lingkungan dengan baik sehingga dapat terhindar dari penyakit menular yg disebabkan oleh mikroorganisme patogen. seperti halnya yang dikemukakan oleh Notoatmodjo (2011) bahwa masalah kesehatan seperti penyakit menular ini dapat ditanggulangi dengan memiliki dasar pengetahuan yang cukup baik mengenai caracara memelihara kesehatan, kemudian memiliki reaksi perasaan, dan kecendrungan untuk bertindak dengan peduli terhadap penyakit menular serta faktor-faktor yang mempengaruhi kesehatan.

\section{KESIMPULAN}

Berdasarkan hasil penelitian yang telah dilakukan, maka didapatkan kesimpulan penelitian ini bahwa terdapat hubungan antara pengetahuan mikrobiologi dengan sikap hygiene mahasiswa Akper Kesdam I/BB Padang, dengan kontribusi 11,4\% terhadap taraf signifikan $\alpha=0,05$ (5\%) dimana $\mathrm{r}$ hitung $=0,338>\mathrm{r}$ tabel $(0,312)$.

\section{SARAN}

Disarankan bagi peneliti selanjutnya dapat menambah variabel penelitian yang lain dan dengan jumlah sampel yang lebih besar agar didapatkan hasil yang lebih akurat.

\section{DAFTAR PUSTAKA}

Devkota, H. R., Murray, E., Kett, M., \& Groce, N. (2017). Healthcare provider's attitude towards disability and experience of women with disabilities in the use of maternal healthcare service in rural Nepal. Reproductive health, 14(1), 79.

Hiyaranya P, Meganada dkk. (2017). Mikrobiologi. Jakarta : Kemenkes RI.

Jamanti, R. (2014). Pengaruh berita banjir di koran Kaltim terhadap Kesadaran Lingkungan Masyarakat Kelurahan Temindung Permai Samarinda. Journal Ilmu Komunikasi, 2(1), 17-33.

Kusuma, Y. DAFTAR PUSTAKA. Achmadi, UF (2011). Dasar-dasar penyakit berbasis lingkungan. Jakarta: Rajawali Press.

Maryunani, A., 2013. Perilaku Hidup Bersih dan Sehat (PHBS). In Jakarta: CV. Trans Info Media, pp : 30-56.

Mustikawati, I. S. (2013). Perilaku personal hygiene pada pemulung di TPA kedaung wetan tangerang. In Forum Ilmiah(Vol. 10, No. 1, pp. 27-35).

Notoatmodjo, S. (2010). Ilmu perilaku kesehatan. Jakarta: rineka cipta, 200, 26-35.

Notoatmodjo, S. (2011). Kesehatan masyarakat. Jakarta: Rineka Cipta, 413.

Rizqah, Z., Setyaningsih, M., \& Mayarni, M. (2019). Hubungan Pengetahuan Mikrobiologi dengan Sikap Peduli terhadap Kesehatan Pada Mahasiswa Pendidikan Biologi. BIOEDUSCIENCE: Jurnal Pendidikan Biologi dan Sains, 3(1), 7-13. Sajida, A., Santi, D. N., \& Naria, E. (2013). Hubungan personal hygiene dan sanitasi 
lingkungan dengan keluhan penyakit kulit di Kelurahan Denai Kecamatan Medan denai Kota Medan Tahun 2012. Lingkungan dan Keselamatan Kerja, 2(2), 14632.

Sarwono \& Widianti. (2011). Gizi Anak Usia Dini. Jakarta : Rineka Cipta.

Steven, P. J. M. (2000). Ilmu keperawatan, jilid I, edisi II. Jakarta: $E G C$.

Yodong dkk. (2019). Hubungan antara tingkat pengetahuan mikrobiologi dengan perilaku hidup bersih dan sehat mahasiswa pendidikan biologi UIN Walisongo Semarang (Doctoral dissertation, UIN Walisongo).

Wijaya, Y. F., \& Muchtar, H. (2019). Kesadaran Masyarakat Terhadap Kebersihan Lingkungan Sungai. Journal of Civic Education, 2(5), 405-411.Hasmiati. 2016. Hubungan Pengetahuan Mikrobiologi dengan Sikap Higienis Mahasiswa Pendidikan Biologi Angkatan 2013 Fakultas Tarbiyah Dan Keguruan Uin Alauddin Makassar. Jurnal Biotek : Vol. 4 No. 2. 
Jurnal Ilmiah Cerebral Medika.Vol.2.No 2 (2020)

Vol.2.No 2 (2020)

p-ISSN :2657-2435

e-ISSSN:2721-3145 